\title{
Preparation for Working Readiness Vocational Education Graduate with Self-Concept and Self-Efficacy Development
}

\author{
Novi Trisnawati \\ Fakultas Ekonomi Universitas Negeri Surabaya \\ Email: novitrisnawati@unesa.ac.id
}

\begin{abstract}
This article aims to examine the efforts that need to be done in facing the readiness of the working world for vocational education by developing self-concept and self efficacy. The increasingly intense work competition in the current era makes vocational education graduates should prepare themselves to be better prepared in facing the world of work. This is done by developing self-concept that can be formed through the planting of strong religious values, self-confidence, self-acceptance. The more we have a positive self-concept then success will be as expected. Selfefficacy is a physiological and emotional condition, expected to increase the ability to work and adapt to the work environment more easily, because self efficacy shows the implementation of processes that have been done during the previous learning process.
\end{abstract}

Keywords: working readiness, self concept, self efficacy

Globalization nowadays making higher working competition. Every industry in working industry effort to do improvement of their quality and working productivity. Preparation which done is receive new employee who ready for work. Preparation to enter working industry is a problem which didn't easy to overcome. High competition which student have to face by vocational education graduate. When some graduates ask where they will work after they graduate, they will say "I don't know", need to continue to higher level or something else. Besides, they also will answer "nowadays is difficult to find a job". This condition describe that didn't yet readiness of some vocational education graduates in order to enter working industry. Employee candidate have to prepare themselves with skills which needed in work industry. Educational institution which preparing employee to ready for work is vocational education.

Vocational education is education which focusing into practical skill which needed for directly go to working industry. Based on News in Education and Cultural Ministry (2016), vocational education need to make specialist which tough and international competitiveness. Because of that condition, government doing SMK strengthen effort as vocational education institution through several dimensions. Those dimensions are strengthening of institution management through school accreditation and certification acceleration, curriculum refinement, and learning quality through specialization spectrum management and increasing industry internship, providing major teacher, and teaching force which competence through industry internship for teacher, also increasing quantity of employee from 
vocational education graduate through graduate portfolio strengthen. So, young generation nowadays don't only have skill, but also tough mental. Vocational education graduates have to ready yet for facing global challenge.

Besides those factors, external factor is pushing and demanding vocational education graduates. High competitiveness and little chance for enter to working industry, beside that also related with free-trade era, so it causing fresh graduates which difficult to enter. Those things happened in every employee recruitment, high demand but low vacancy, it happened in government sector and private which in the country and overseas, so formation which provide become competition. Vocational education graduate which working besides their competency also which didn't yet get a job because self-acknowledge which lack of their self-concept. Someone's self-concept toward lack of working readiness will get special attention of vocational educational institution. This thing caused vocational education graduate still have difficulty to decide their career when they graduate. This selfconcept which important to developed in students.

Better or positive self-concept which have by someone will make easier to achieve successfulness. Based on Desmita (2014), this thing caused good or positive self-concept then someone will optimistic, want to try something new, dare to success and failed, full confidence and enthusiast, feels happy, have life objective, also have positive attitude and thinking. Otherwise, worse or negative self-concept, then it's more difficult to someone to succeeded, because worse or negative selfconcept will grow unconfident feeling, afraid for failing so didn't dare to try something new and challenging, feeling stupid, and feel useless, pessimistic, also sharing inferior feelings and behavior. Vocational education graduate in order to facing working industry not only paying attention to self-concept, but also other factors also affecting in preparation to facing working industry.

One of other factors which affecting individual working readiness is selfefficacy. Good self-efficacy in students needed for students to prepare enter working industry. Students who success know their self-capability will feels confidence to get a job. This thing depends on positive individual image in their own. More capable someone to give positive image of their capability so have bigger chance to get a job. Students who have high self-efficacy, will knows how their capability in order to face working industry. Someone who have low self-efficacy less knowing how their capability to face working industry. This self-efficacy leading individual to understand their condition realistically, so individual able to adjust between their dream job with their individual capability which they have.

\section{DISCUSSION}

Working industry not only choosing employee candidate which expert in academic capability (hard skills), but also attention to other values which are honest, responsible, communication, and leadership values (soft-skill). Having good skill capability but didn't complete with good soft skill, will produce human resources with less maximal skills. Competition is stricter, working industry also try to compete with others is by improving quality or not only product quality, but also in consumer services. 
Based on phycology dictionary (Chaplin, 2011) working readiness consist two explanations are: (a) ready condition for react and respond, (b) development level of maturity which advantage to practice something. Working readiness defined by Hersey and Blanchard is how capability and readiness level which someone have to complete certain task (Robbins, 2007). Udith O. Wagner in Firdaus (2012) said that working readiness is a set of skill and behavior which needed for work in every job.

Skill for working readiness called soft skills, working skill, or working readiness skill. From those variation of definition, but essentially have same meaning. Working readiness based on Wagner include several aspects are: (1) reading information skill; (2) applied mathematics; (3) business writing; (4) writing and searching information; (5) teamwork; (6) observation; (7) listening; and (8) applied technology. While based on Firdaus (2012) said research result which done shows good SMK students working readiness level, this synergy effort to maintain and increase by all party, such as parent, school, society, and government with giving advisory continuously and sustainable. Because of that, it can be concluded that readiness is ready for give respond or react. That readiness come from themselves and correlate with maturity. Readiness need to give attention in some process, because if student have readiness, result will be satisfied.

Utami (2013) said that SMK student which have age about 16-19 years old, then students need to get preparation of working readiness, because characteristic which they have, are consist of teenager which in their development age adaptive to study, have value to their development need instrument in SMK, so they able to adapt with their social environment, able to get achievement continuously and have independency, know environment, social cultural and knows capability. Many people which have assessment that working industry have relation with environment, communication, task which need good mental and physic readiness, capability to communicate and everything which need to be serious and special skill.

Working readiness in productive age, especially SMK student not only made from knowledge, need counseling to made attitude which ready to enter working industry. Advisory and counseling appear form job problem or level, then develop to other section is career advisory. Because of that, to get job which relevant with everything inside individual also to make good attitude to enter working industry, need good advisory. Implementation of career advisory produce good synergy to made readiness are mental and emotional in students as basic readiness for work. Some effort which didn't easy to understand correlation themselves with future in order to find potency which able to give later to fulfill need through working activity.

Based on Rifa'I and Anni (2011:105) study is behavioral changing process. Those behavioral changing needs a stimulus so, able to produce responds. For achieving good result, then needed individual readiness in study (Rifa'I dan Anni, 2011:116). If individual able to do something which relevant to self-readiness, so they will get satisfaction. There is three condition which showing readiness theory by Thorndike in Rifa'I and Anni (2011:116) are: (a) if individual have readiness to action or behave and they able to do it, they will feel satisfaction; (b) if individual have readiness to action or behave and didn't able to do it, they will feel disappointed; (c) if individual didn't have readiness to action or behave, and force to do it, it will make unsatisfied condition. 
Readiness is condition where someone which preparing to give respond or answer in certain way toward some situation (Slameto, 2010:113). So, working readiness is condition where someone able to give their respond to facing working industry using body strength, thinking, mind, skill, knowledge in order to fulfill needs.

Based on Slameto (2010:113) condition which affecting working readiness are: (a) physical, mental, and emotional condition. Including temporary physic condition (tired, condition, sense, and other); (b) needs, motive, and objective. Needs which realize or didn't realize. Needs which based on effort through motive and purpose which they have; (c) skill, knowledge, and other description which have been learned. Skill, knowledge, and other description which have been learned will increase readiness for doing something.

Working readiness based on Slameto (2010:115): (a) all development aspects interact each other; (b) physical and mental readiness is need to get advantage from experience; (c) experiences have positive influence toward readiness; (d) basic readiness to certain activity formed in certain period. While Dalyono (2009) aspect which made, working readiness are: (a) maturity is a form, structure, and function condition which complete or mature in some organism, not only some traits but also other traits. Maturity made attitude and power to react in some way which called readiness; (b) environment and culture development depend on environment and culture influence.

Explaining about working readiness able to conclude that readiness is condition and situation of vocational education graduate where graduates have attitude which ready to get response of what they will be done or ready to do some activity which relevant with their capability and specialty also able to be advantage for them and their environment. Development need many skilled, educated, and trained workforce which have readiness to enter working industry. Achievement of those readiness have to do through many processes which involving many factors in it. Readiness is main capital for someone to do every job so with this readiness able to got maximal result. Readiness depend on maturity level, past experience, emotional condition, and mental from student.

SMK student's readiness toward jobs didn't come accidentally, otherwise through several processes. Those process is right self-concept making, industrial practice, and collecting information related to working industry. The right introduction of self-concept, working industrial practice experience, and knowledge about working industry information then student will able to determine job which relevant with condition of their self because introduction of good self-concept about their capability and quality.

Based on Rakhmat (2001) explain that factors which affecting self-concept are: (a) significant others is someone who most influencing in individual life, (b) reference group is group which emotionally bonding individual and influencing toward forming of individual self-concept. While, based on Brooks (1971 in Sobur, 2003) saying that there is several factors which influencing in self-concept are: (a) self-appraisal, (b) reaction and response of others, (c) role play-role takin, (d) reference group.

Based on Rifa'I and Anni (2011:105) study is behavioral changing process. Those behavioral changing needs a stimulus so, able to produce responds. For 
achieving good result, then needed individual readiness in study (Rifa'I dan Anni, 2011:116). If individual able to do something which relevant to self-readiness, so they will get satisfaction. There is three condition which showing readiness theory by Thorndike in Rifa'I and Anni (2011:116) are: (a) if individual have readiness to action or behave and they able to do it, they will feel satisfaction; (b) if individual have readiness to action or behave and didn't able to do it, they will feel disappointed; (c) if individual didn't have readiness to action or behave, and force to do it, it will make unsatisfied condition.

Everyone have different self-concept each other. Which have negative selfconcept and also have positive self-concept. Positive or negative self-concept able to made by several things. Positive self-concept able to made through religion value, self-confidence, and self-acceptance. For negative self-concept, able to made by lack of attention, lack of religion values, lack of confidence, and didn't able to accept their self. When we open ourselves, will make our self-concept more reality. While advantage of open minded to other will able to know feedback for us, so this feedback will make easier to self-acknowledge process. Because of those condition, result not only able to feel as our weakness, but also able to fix it. Otherwise, we able to know about our advantage which will be able to use for better things.

One of the other specific capability which have to had by job seeker is ability or mental readiness. Someone which have good mental maturity will be able to rise self-efficacy or their faith in order to face new environment where student will work. Based on Vouri's research result (2005) said that to get behavioral change in future then need to have skill and self-efficacy which hopefully get good result in behave to face working industry. Self-efficacy has important role in order to overcome problem which faced by individual. Students preparing to facing working industry sometimes has constraint. Student's effort to overcome constraint so ready to enter working industry influenced by self-efficacy. Self-efficacy is one of knowledge aspect about themselves which most influencing in everyday live. This thing caused selfefficacy which have influencing individual in order to determine action which will do to achieve a purpose or someone successfulness, included prediction several conditions which will face.

Working industry is different with academic, rough live, responsible which we have to take is different where we live in school. Self-efficacy also able to give support for individual to evaluate their self so able to face working demand and dynamic competition. Evaluation someone toward their capability (self-efficacy) have importance role in individual development process, especially related with capability in order to solve their problem. Bandura (1997) definite self-efficacy as a someone faith with their capability to form and leading their behavior to reach result which they want. Self-efficacy is self-perception about how good themselves facing in certain situation. Self-efficacy related to faith that they have capability to action which they want (Alwisol, 2008).

Bandura said that self-efficacy is result of cognitive process in decision, faith, or hope about how far student predict their capability in order to do task or certain action which needed for achieve good result (Ghufron, 2011). Based on Bandura, self-efficacy not related with skill which they have, but related with individual faith about things which able to do with individual skill which they have. Self-efficacy focused on confidence component which student have in order to face condition 
which will come don't able to predict and full of pressure. Self-efficacy combine with environment, previous behavior, and other personal behavior, especially hope toward result to change behavior.

High self-efficacy needs opportunity to develop through practice which done continuously and done early which relevant with ability which student have. Support from family also environment needed for achieve faith of self-capability. Role of teacher, parents, and response from environment needed for student as enforcement to every effort which they have done, student will be motivated, confidence, and able to overcome constraint or problem so students more ready to face working industry.

Increasing of student working readiness is important thing so student able to get a job. One of factors which influence this readiness is self-efficacy. Self-efficacy which reflect from student formed through learning process which happened in interaction with environment. Study is a process which done by someone to get a behavior change comprehensively, as result of their experience in interaction with their environment (Slameto, 2010:2). Having of this self-efficacy hopefully able to increase student's working readiness and adapt with working environment easily, because self-efficacy showing implemented learning process which done by student through behavioral change which able to form working readiness,

Self-efficacy get and developed through some combination from four sources, are: (a) mastery experiences, sources which most affecting for self-efficacy is experience about mastery, is performance which done in the past. Sometimes, performance successful will making expectations toward self-capability to affecting result which they want, while failure tent to lower self-efficacy; (b) social modeling, second sources of self-efficacy is social modeling, is vicarious experience which provide by others. Self-efficacy increasing when someone watching other achievement which same level with us, social modeling only give small effect for selfefficacy; (c) social persuasion, self-efficacy also can achieve or weaken through social persuasion. Effects of this sources is limited, but in right condition, other persuasion able to increase or decrease self-efficacy; (d) physical and emotional states.

Last source of self-efficacy is physiology and emotional condition. Strong emotion sometime decrease performance level. While feeling fear, over worried, and high stress, human will have lower self-efficacy. Based on Rogers in Alwisol (2009: 209), every individual has different self-efficacy in different situation based on: (a) capability which demanded by different situation; (b) other present, especially competitor in some situation; (c) physiology and emotional condition; tired, worried, apathic, sad.

\section{CONCLUSION}

Self-concept and self-efficacy important in order to prepare facing working industry. So, in order to prepare facing those working industries need an effort for improving self-efficacy so self-confidence is increasing and developing optimally so get job which they want.

Working readiness showing conditions where somebody able to give their respond to facing working industry using body strength, think, mind, skill, and 
knowledge in order to fulfill needs. Besides, for supporting those preparations need have positive self-concept which able formed through strong religion values, selfconfidence, self-accepting. While, for negative self-concept able to formed by lack of attentions. Other things which support working readiness is self-efficacy through development in order to take decision, faith or hope about how far individuum thinking about their capability in order to do task or certain task which needs for reach result which they wanted.

\section{REFERENCES}

Alwisol. 2010. Psikologi Kepribadian. Malang: UMM Malang.

Bandura, A. 1997. Efikasi diri the exercise of control. New York: Stanford University.

Clarke, L and Winch. C. 2007. Vocational Education International Approach, Development and System. New York: Routledge.

Chaplin, J. P. 2011. Kamus lengkap psikologi. Jakarta: PT RajaGrafindo Persada.

Dalyono, M. 2009. Psikologi Pendidikan. Jakarta: PT Rineka Cipta.

Desmita. 2014. Psikologi Perkembangan Peserta Didik. Bandung : Remaja Rosdakarya.

Firdaus, Z. Z. 2012. Pengaruh Unit Produksi, Prakerin dan Dukungan Keluarga Terhadap Kesiapan Kerja Siswa SMK. Jurnal Pendidikan Vokasi. 1 (3), diakeses November 2012.

Ghufron, M. N., \& Rini R. 2011. Teori-teori psikologi. Jogjakarta: Ar-Ruzz Media.

Kemendikbud. 2016. Kemendikbud Dorong Pendidikan Vokasi Berdaya Saing Internasional.

https://www.kemdikbud.go.id/main/blog/2016/08/kemendikbud-dorongpendidikan-vokasi-berdaya-saing-internasional. Diakses tanggal 10 Mei 2017.

Rakhmat, J. 2001. Psikologi Komunikasi. Bandung : PT. Remaja Rosdakarya.

Rifa'i, A. dan Catharina T. A. 2011. Psikologi Pendidikan. Semarang: UNNES Press.

Robbins, P. S. \& Judge, A. T. 2007. Perilaku organisasi (Ed. 12). Jakarta: Salemba Empat.

Slameto. 2010. Belajar dan Faktor-faktor yang Mempengaruhinya. Jakarta: Rineka Cipta.

Sobur, A. 2003. Psikologi Umum. Bandung: CV.Pustaka Setia. 
Utami, Y. G. dan Hudaniah. 2013. Efikasi diri dengan Kesiapan Kerja Siswa Sekolah Menengah Kejuruan. Jurnal Ilmiah Psikologi Terapan. 01:01.

Vuori, J. 2005. Job-search preparedness as a mediator of the effects of the Tyohon Job Search Intervention on re-employment and mental health. Journal of Organizational Behavior J. Organiz Behav. 26:275-291. 